\title{
THE FUTURE OF ALLIED HEALTH LEADERSHIP IN NEW ZEALAND - AOTEAROA: A LITERATURE REVIEW
}

\author{
Rebecca Kate Georgel, Karen Webster² \\ 1. Canterbury District Health Board, Health Informatics New Zealand, Australasian Institute of Digital Health \\ 2. Paramedicine Department, School of Clinical Sciences, Auckland University of Technology, New Zealand
}

Correspondence: becky.george@hotmail.co.nz

\begin{abstract}
\section{BACKGROUND:}

The allied heath, scientific and technical (allied health) workforce is the second largest workforce in New Zealand, providing diagnostic, therapeutic and preventative services. Increasingly consumers present with complex conditions requiring multiprofessional integrated services and a legacy of profession-focused leadership development is being challenged. [1] Future health and disability systems require leaders prepared to lead complex services, less focussed on their professional background and more on understanding their interprofessional services. [2,3] The Allied health workforce is well placed to lead these systems, providing interprofessional experience, a biopsychosocial lens and collaborative models of practice.
\end{abstract}

AIM:

To provide an understanding of the literature and research available that addresses the leadership of healthcare services by allied health clinicians.

\section{METHODOLOGY:}

An initial database review was completed using a systematic approach, across CINAHL complete; EBSCO Business; Medline; and EBSCO Health databases from March 2020 to September 2020. An expanded search used Google Scholar and NZ, UK and Australian based government websites to access institutional documents, such as policies, reviews and reports.

\section{RESULTS:}

The review identified an emerging pool of research on allied health leadership in Australia and the UK but a paucity of literature on allied health leadership in New Zealand. Three themes were identified and explored within the article: health leadership frameworks, current state and barriers and enablers identified.

\section{CONCLUSIONS:}

Literature advocates for a broader scope of clinicians into strategic leadership roles. Despite evidence of strategic allied health roles in New Zealand there remains a dearth of literature on allied health leadership. To foster and sustain the development of allied health leaders in New Zealand it is important to understand the enablers that impact this process.

\section{KEYWORDS}

allied health, leadership, health system, disability, New Zealand, Aotearoa 


\section{INTRODUCTION}

Healthcare is known for its complexity, its workforce diversity and ongoing financial challenges. It also continually presents more adaptive requirements than we can implement solutions to resolve. A health workforce looks to the health and disability system leadership to provide vision, direction and clarity. [1-3] Establishing effective leadership in healthcare across services, systems and the workforce, is key to supporting the provision of high-quality treatment, optimal results and the ongoing development of consumer-focused services. [1, 4-6] As healthcare continues to evolve in response to population diversity, digital technology development and health need, it is suggested the recruitment of the most effective leadership possible is a logical objective.

New Zealand's allied health, scientific and technical collective of professions is a significant proportion of the health workforce. According to district health boards (DHBs)New Zealand [8] the employed workforce number 12,683 . This compares with 5,781 Senior Medical Officers and 30,355 Nurses. Allied Health Aotearoa New Zealand [9] report that the allied health collective across both public and private sectors comprise more than 30,000 clinical professionals across 50 different professions, providing diagnostic, preventative and rehabilitative services. This makes allied health the second largest workforce in public health in New Zealand.

This article presents a review of the literature addressing leadership by allied health clinicians within the context of health and disability services internationally, regionally and locally in New Zealand. The themes identified include, health leadership frameworks, current state and the barriers and enablers to allied health leadership.

\section{METHODOLOGY}

A narrative literature review using a systematic approach to searching was undertaken to identify relevant literature on healthcare services leadership by allied health clinicians, seeking to gain an overview of the current state of research and empirical evidence available. [7] The search utilised electronic databases between March 2020 to September 2020, specifically: CINAHL Complete (Cumulative Index to Nursing and Allied Health Literature), EBSCO Business; Medline; and EBSCO Health databases. Search terms used were, health*, lead*, manage*, (multiprofessional or multidisciplinary), and (NZ, New Zealand or Aotearoa). Terms were used in combination and with the 'AND' Boolean. Database searches were initially limited to English-only citations published after 2013 to ensure relevancy and utilise the most recent research available. Peer-reviewed literature that addressed leadership methods, processes, case studies, frameworks and theory development were included. Conference papers, books and book chapters on allied health leadership were excluded, as were papers focused on disciplines whose context of practice was external to the public health and disability system, such as sports training or coaching. Due to a lack of research literature available using these parameters, key papers prior to 2013 were included and Google Scholar and NZ, UK and Australian based government websites provided access to relevant institutional documents, such as policies, reviews and reports.

EndnoteX9 software was used to manage the exclusion of duplicates and refine management of the references by keyword tagging and categorisation. Microsoft Excel provided the platform for data synthesis, utilising the headings of author, theme, year, title, topic, methodology, findings, argument, and limitations to find emergent themes, commonalities and differences. The use of coding and identifying direct quotes enabled the researcher to synthesise the literature available according to their outcomes or perspectives. This supported the development of the key thematic areas addressed within existing evidence and an overall understanding of the current context of allied health leadership. The total number of articles found $n=21$ are summarised in Table 1 . 


\begin{tabular}{|c|c|c|c|c|c|}
\hline AUTHOR & YEAR & COUNTRY & TITLE & TOPIC & FINDINGS \\
\hline Boyce R et al. & 2017 & Australia & $\begin{array}{l}\text { Allied Health } \\
\text { Leaders: Australian } \\
\text { Public Health Boards } \\
\text { and Top } \\
\text { Management Teams }\end{array}$ & $\begin{array}{l}\text { Overview of } \\
\text { allied health } \\
\text { leadership } \\
\text { positioning }\end{array}$ & $\begin{array}{l}\text { AH is underrepresented on Top } \\
\text { Management Teams. AH only make } \\
\text { up a quarter of the board positions. }\end{array}$ \\
\hline Bradd T et al. & 2018 & Australia & $\begin{array}{l}\text { AH Leadershipin } \\
\text { NSW: a study of } \\
\text { perceptions and } \\
\text { priorities of AH } \\
\text { leaders }\end{array}$ & $\begin{array}{l}\text { Views and } \\
\text { perceptions of } \\
\text { AH leadership }\end{array}$ & $\begin{array}{l}\text { Identified need to build and grow } \\
\text { influence, demonstrate AH } \\
\text { contribution, focus efforts on } \\
\text { governance, performance, } \\
\text { standards and advocacy. To } \\
\text { increase scope of AH directors and } \\
\text { across profession leaders. }\end{array}$ \\
\hline $\begin{array}{l}\text { Edmonstone, } \\
\text { John }\end{array}$ & 2013 & England & $\begin{array}{l}\text { What is wrong with } \\
\text { NHS leadership } \\
\text { development? }\end{array}$ & $\begin{array}{l}\text { Leader } \\
\text { developmentvs } \\
\text { leadership } \\
\text { development }\end{array}$ & $\begin{array}{l}\text { Principles outlined for leadership } \\
\text { development }\end{array}$ \\
\hline $\begin{array}{l}\text { Forsyth and } \\
\text { Mason }\end{array}$ & 2017 & England & $\begin{array}{l}\text { Shared leadership } \\
\text { and group } \\
\text { identification in } \\
\text { healthcare: the } \\
\text { leadership beliefs of } \\
\text { clinicians working in } \\
\text { interprofessional } \\
\text { teams }\end{array}$ & $\begin{array}{l}\text { The leadership } \\
\text { beliefs of } \\
\text { clinicians in } \\
\text { interprofessional } \\
\text { teams - are they } \\
\text { associated with } \\
\text { professional or } \\
\text { team identities. }\end{array}$ & $\begin{array}{l}\text { No difference between professions } \\
\text { about beliefs in shared leadership. } \\
\text { Group identification link to } \\
\text { clinician's leadership beliefs. }\end{array}$ \\
\hline Fry K & 2010 & $\begin{array}{l}\text { New } \\
\text { Zealand }\end{array}$ & $\begin{array}{l}\text { Social Work clinical } \\
\text { leadership in allied } \\
\text { health }\end{array}$ & $\begin{array}{l}\text { Clinical } \\
\text { leadership in } \\
\text { social work in } \\
\text { allied health in } \\
\text { NZ }\end{array}$ & $\begin{array}{l}\text { There are challenges and } \\
\text { opportunities to use and develop } \\
\text { skills and knowledge and practice } \\
\text { to provide ah with unity and } \\
\text { direction }\end{array}$ \\
\hline Garmanet al. & 2019 & USA & $\begin{array}{l}\text { Bridging Worldviews: } \\
\text { Toward a common } \\
\text { model of leadership } \\
\text { across the health } \\
\text { professions. }\end{array}$ & $\begin{array}{l}\text { Revising and } \\
\text { validating an } \\
\text { interprofessional } \\
\text { leadership } \\
\text { competency } \\
\text { model }\end{array}$ & $\begin{array}{l}\text { Competencies all met the criteria } \\
\text { for validity, } 85 \% \text { of the } \\
\text { competencies also mapped to } 5 \\
\text { other professional leadership } \\
\text { models. Revised model is able to } \\
\text { provide a common language } \\
\text { framework for interdisciplinary } \\
\text { leadership development }\end{array}$ \\
\hline Gifford et al. & 2018 & Canada & $\begin{array}{l}\text { Managerial } \\
\text { leadership for } \\
\text { research use in } \\
\text { nursing and allied } \\
\text { health care } \\
\text { professions: a } \\
\text { systematic review }\end{array}$ & $\begin{array}{l}\text { The association } \\
\text { between } \\
\text { leadership } \\
\text { behaviours and } \\
\text { nurse and AHPs } \\
\text { use of research }\end{array}$ & $\begin{array}{l}\text { Managers performed a diverse } \\
\text { range of leadership behaviours - } \\
\text { change oriented, relation oriented, } \\
\text { and task oriented. Most common } \\
\text { was support for the change. }\end{array}$ \\
\hline
\end{tabular}




\begin{tabular}{|c|c|c|c|c|c|}
\hline Gordon et al. & 2015 & UK & $\begin{array}{l}\text { Dimensions, } \\
\text { discourses and } \\
\text { differences: trainees } \\
\text { conceptualising } \\
\text { health care } \\
\text { leadership and } \\
\text { followership }\end{array}$ & $\begin{array}{l}\text { What does } \\
\text { leadership and } \\
\text { followership } \\
\text { mean to } \\
\text { medical } \\
\text { trainees working } \\
\text { in today's } \\
\text { interprofessional } \\
\text { health care } \\
\text { workplace }\end{array}$ & $\begin{array}{l}\text { dominance of individualistic } \\
\text { discourse (hierarchy, personality } \\
\text { and individual behaviours), context } \\
\text { heavily influenced trainee's } \\
\text { conceptualisations. }\end{array}$ \\
\hline $\begin{array}{l}\text { Marinelle- } \\
\text { Poole et al. }\end{array}$ & 2011 & $\begin{array}{l}\text { New } \\
\text { Zealand }\end{array}$ & $\begin{array}{l}\text { New Zealand Health } \\
\text { Leadership }\end{array}$ & $\begin{array}{l}\text { The comparison } \\
\text { of two different } \\
\text { approaches to } \\
\text { leadership } \\
\text { development } \\
\text { used in District } \\
\text { Health Boards }\end{array}$ & $\begin{array}{l}\text { Two distinct models of approach - } \\
\text { no quantifiable outcomes } \\
\text { demonstrated. }\end{array}$ \\
\hline Markham D & 2015 & Australia & $\begin{array}{l}\text { Allied Health: } \\
\text { leaders in health } \\
\text { care reform }\end{array}$ & $\begin{array}{l}\text { The potential for } \\
\text { allied health } \\
\text { workforce to } \\
\text { demonstrate } \\
\text { leadershipin } \\
\text { healthcare } \\
\text { reform }\end{array}$ & $\begin{array}{l}\text { Health care challenges can be met } \\
\text { by allied health workforce actively } \\
\text { and effectively. }\end{array}$ \\
\hline $\begin{array}{l}\text { McGowan et } \\
\text { al. }\end{array}$ & 2018 & Ireland & $\begin{array}{l}\text { Leadership } \\
\text { capabilities of } \\
\text { physiotherapy } \\
\text { leaders in Ireland: } \\
\text { Part 2. Clinical } \\
\text { Specialists and } \\
\text { Advanced } \\
\text { Physiotherapy } \\
\text { Practitioners }\end{array}$ & $\begin{array}{l}\text { Do Clinical } \\
\text { Specialists and } \\
\text { Advanced } \\
\text { Physiotherapy } \\
\text { Practitioners } \\
\text { identify with } \\
\text { leadership } \\
\text { capability }\end{array}$ & $\begin{array}{l}\text { Sample identified capabilities } \\
\text { associated with all four domains. } \\
\text { Predominance of skills in the human } \\
\text { resource frame. Less in political and } \\
\text { symbolic frames - same as physio } \\
\text { managers }\end{array}$ \\
\hline $\begin{array}{l}\text { McGowan et } \\
\text { al. }\end{array}$ & 2018 & Ireland & $\begin{array}{l}\text { Leadership } \\
\text { capabilities of } \\
\text { physiotherapy } \\
\text { leaders in Ireland: } \\
\text { Part } 1 . \\
\text { Physiotherapy } \\
\text { Managers }\end{array}$ & $\begin{array}{l}\text { Do Physio } \\
\text { managers } \\
\text { identify with } \\
\text { leadership } \\
\text { capabilities } \\
\text { across the four } \\
\text { domains of the } \\
\text { Bolman and } \\
\text { Deal framework }\end{array}$ & $\begin{array}{l}\text { Sample identified capabilities } \\
\text { associated with all four domains. } \\
\text { Predominance of skills in the } \\
\text { structural and human resource } \\
\text { frames. Symbolic frame was } \\
\text { underused, fewer examples } \\
\text { evidencing communication of } \\
\text { vision, demonstrating passion and } \\
\text { facilitating positive workforce } \\
\text { culture. }\end{array}$ \\
\hline McGrath et al. & 2019 & USA & $\begin{array}{l}\text { International } \\
\text { interprofessional } \\
\text { leadershipin }\end{array}$ & $\begin{array}{l}\text { Description of } \\
\text { interprofessional } \\
\text { training } \\
\text { programme, }\end{array}$ & $\begin{array}{l}\text { Self-reported outcomes and in- } \\
\text { depth focus on self, team and } \\
\text { wider community }\end{array}$ \\
\hline
\end{tabular}




\begin{tabular}{|c|c|c|c|c|c|}
\hline & & & $\begin{array}{l}\text { maternal and child } \\
\text { health }\end{array}$ & $\begin{array}{l}\text { evaluation and } \\
\text { implications }\end{array}$ & \\
\hline $\begin{array}{l}\text { McKeever and } \\
\text { Brown }\end{array}$ & 2019 & Australia & $\begin{array}{l}\text { What are the client, } \\
\text { organisational and } \\
\text { employee related } \\
\text { outcomes of high } \\
\text { quality leadership in } \\
\text { the Allied Health } \\
\text { professions? A } \\
\text { Scoping Review }\end{array}$ & $\begin{array}{l}\text { Qualitative } \\
\text { outcomes as a } \\
\text { result of high- } \\
\text { quality } \\
\text { leadership }\end{array}$ & $\begin{array}{l}35 \text { articles. Lack of viable AH } \\
\text { research. } 4 \text { styles of leadership } \\
\text { prevalent, traits of an effective } \\
\text { leader identified, specific examples } \\
\text { of outcomes relating to client, } \\
\text { organisation and employee when } \\
\text { leadership is effective. }\end{array}$ \\
\hline Mickan et al. & 2019 & Australia & $\begin{array}{l}\text { Realist evaluation of } \\
\text { allied health } \\
\text { management in } \\
\text { Queensland: what } \\
\text { works, in which } \\
\text { contexts and why. }\end{array}$ & $\begin{array}{l}\text { Which key } \\
\text { organisational } \\
\text { contexts and } \\
\text { mechanisms } \\
\text { influenced } \\
\text { outcomes for } \\
\text { Allied Health } \\
\text { Professionals }\end{array}$ & $\begin{array}{l}\text { Identification of mechanisms that } \\
\text { work to achieve effective and } \\
\text { efficient outcomes }\end{array}$ \\
\hline $\begin{array}{l}\text { Orton and } \\
\text { Hocking }\end{array}$ & 2017 & $\begin{array}{l}\text { New } \\
\text { Zealand }\end{array}$ & $\begin{array}{l}\text { Clinical } \\
\text { Governance: } \\
\text { Implications for } \\
\text { occupational } \\
\text { therapists in } \\
\text { Aotearoa New } \\
\text { Zealand }\end{array}$ & $\begin{array}{l}\text { Exploring the } \\
\text { impact of NZ's } \\
\text { Clinical } \\
\text { Governance } \\
\text { (CG) framework } \\
\text { on } \\
\text { Occupational } \\
\text { Therapy } \\
\text { practice in NZ. }\end{array}$ & $\begin{array}{l}\text { CG is poorly understood, CG gives } \\
\text { therapists responsibility for quality } \\
\text { improvement. Expectations for } \\
\text { clients to take responsibility may not } \\
\text { be achievable by all. OTs need to } \\
\text { consider how to respond to CG. } \\
\text { CG requires leadership - but due to } \\
\text { poor understanding leadership may } \\
\text { not be fulfilled. }\end{array}$ \\
\hline Scott et al. & 2018 & Canada & $\begin{array}{l}\text { Building Healthcare } \\
\text { Leadership } \\
\text { Capacity: Strategy, } \\
\text { Insights and } \\
\text { Reflections }\end{array}$ & $\begin{array}{l}\text { Review and } \\
\text { overview of the } \\
\text { Dorothy Wylie } \\
\text { Health Leaders } \\
\text { Institute, } \\
\text { Canada. }\end{array}$ & $\begin{array}{l}\text { Leadership is crucial to the success } \\
\text { in complex healthcare. }\end{array}$ \\
\hline Smith et al. & 2018 & England & $\begin{array}{l}\text { Leadership in } \\
\text { interprofessional } \\
\text { health and social } \\
\text { care teams: a } \\
\text { literature review }\end{array}$ & $\begin{array}{l}\text { A review } \\
\text { examining how } \\
\text { leaders of } \\
\text { interprofessional } \\
\text { teams are } \\
\text { functioning and } \\
\text { synthesis } \\
\text { identifying } \\
\text { factors that } \\
\text { contribute to } \\
\text { good } \\
\text { leadership } \\
\text { practice. }\end{array}$ & $\begin{array}{l}\text { Limited literature. } 28 \text { papers. } 12 \\
\text { domains identified. }\end{array}$ \\
\hline
\end{tabular}




\begin{tabular}{|l|l|l|l|l|l|}
\hline $\begin{array}{l}\text { Wylie and } \\
\text { Gallagher }\end{array}$ & 2009 & Australia & $\begin{array}{l}\text { Transformational } \\
\text { Leadership } \\
\text { Behaviours in Allied } \\
\text { Health Professions }\end{array}$ & $\begin{array}{l}\text { An evaluation } \\
\text { of self- } \\
\text { perceived } \\
\text { leadership } \\
\text { profiles across } \\
\text { different Allied } \\
\text { Health } \\
\text { professions }\end{array}$ & $\begin{array}{l}\text { Significant differences in } \\
\text { transformational leadership } \\
\text { behaviours between individual AH } \\
\text { professions. Radiographers and } \\
\text { Podiatrists scored consistently lower, } \\
\text { seniority of grade influenced scores, } \\
\text { prior training influenced scores. }\end{array}$ \\
\hline $\begin{array}{l}\text { Edmonstone, J } \\
\text { Laculty of } \\
\begin{array}{l}\text { Ledical } \\
\text { and } \\
\text { Management }\end{array}\end{array}$ & 2020 & England & $\begin{array}{l}\text { Beyond healthcare } \\
\text { leadership? The } \\
\text { imperative for health } \\
\text { and social care } \\
\text { systems }\end{array}$ & $\begin{array}{l}\text { Health and } \\
\text { social care } \\
\text { systems } \\
\text { leadership }\end{array}$ & $\begin{array}{l}\text { Health and social care as a system } \\
\text { rather than separate organisations, } \\
\text { developed through systems } \\
\text { leadership. Leadership not } \\
\text { individual leaders. }\end{array}$ \\
\hline $\begin{array}{l}\text { England } \\
\text { Rarriers and enablers } \\
\text { for Clinicians moving } \\
\text { into senior } \\
\text { leadership roles }\end{array}$ & $\begin{array}{l}\text { Clinical } \\
\text { Leadership }\end{array}$ & $\begin{array}{l}\text { Progression to leadership roles rarely } \\
\text { promoted as legitimate career } \\
\text { pathways. Skills and competencies } \\
\text { required were not always clearly } \\
\text { known. Need to identify and } \\
\text { developleadership talent. Lack of } \\
\text { data about the backgrounds and } \\
\text { qualifications of senior NHS leaders. } \\
\text { The need for more Allied Health } \\
\text { leaders identified by existing Allied } \\
\text { Health leaders }\end{array}$ \\
\hline
\end{tabular}

\section{HEALTH LEADERSHIP FRAMEWORKS}

Until July 2022 there are 21 District Health Boards (DHBs) in New Zealand who have a variety of roles at their executive board level. [8] These are led by clinical and non-clinical leaders whose perspective spans clinical and operational systems. Each DHB autonomously creates and shapes their leadership and governance structure according to the perceived need [9] In 2016, the refreshed New Zealand Health Strategy was published providing clear direction to ensuring 'Value and high performance, Te whāinga hua me te tika o ngā mahi' of the health system performing as 'One team, Kotahi te tīma'. The theme 'One team' focuses on building leadership, talent and diversity within the workforce. Reducing fragmentation of services and fostering collaboration are key elements to improving timeliness service provision, access to services and reducing duplication of resource. [10] However, the refreshed strategy only partially achieved the outcomes it sought. A lack of coordinated leadership development across the health and disability workforce emphasised the need to develop leaders early and create deliberate career pathways. [1 1 ]

A key aspect of healthcare governance is the empowerment of clinicians into leadership roles. In 2009, The Ministerial Task Group Report 'In Good Hands: Transforming Clinical Governance in New Zealand' [12] was published outlining the transformative changes required to the leadership of clinicians as well as identifying the need to nurture clinicians into roles to lead. The Task Group reported, 'healthcare that has competent, diffuse, transformational, shared leadership is safe, effective, resource efficient and economical'. [12] However, the implementation of their recommendations on clinical governance has not been without its challenges. Orton and Hocking [13] reported that each DHB was left to interpret the recommendations in their own way and develop their own frameworks. This evidence contradicts the intention of a united and shared vision for a standardised approach to clinical governance. 
Exploring the implications of clinical governance for occupational therapists in NZ, Orton and Hocking [13] affirmed the benefit it has on quality improvement and service reform and concluded that the proposed advantages that clinical governance brings to the development of leadership and the healthcare system in NZ present opportunities but only when it is fully understood. It is suggested we continue to lack a coherent and easily implemented leadership framework for healthcare and disability services in NZ. While there is evidence of DHBs working hard to implement localised leadership development and training courses, they don't have a single framework to reference for consistent and quality assured competency requirements. [3] Garman, Standish [14] suggests that the use of a universal framework or model provides neutral territory for developing programmes. He goes on to claim there are indeed 'more similarities than differences in the leadership development challenges' faced by health systems within a nation (p.9). Although this claim is supported by Marinelli-Poole, McGilvray [3] their case study included only two DHBs in NZ, a sample too small to confirm the claim across NZ healthcare organisations.

Evidence demonstrates that ineffective leadership leads to poor patient outcomes and is associated with inadequately performing healthcare services. [15] The drive therefore for successful outcomes and positive highperformance measures within healthcare systems has seen a diverse number of healthcare service leadership models and provision frameworks across New Zealand and Australia. Modern healthcare is delivered from within a team-based framework utilising a breadth of skills across professions and a focus on positive healthcare experience, which emphasises the critical elements of consumer engagement and consumer centred care. [2, 10] Examples of leadership programmes developed for the New Zealand health service include; The Leading Excellence in Health Care Programme and Xcelr8 [3], i3 Health Leadership [16] and HELM - Hub for the Essentials of Leadership and Management. [17]

In a world where our populations are presenting with more complex conditions, they typically require an approach that has a broader perspective rather than solely a diagnostic focus. According to McKeever and Brown [18] 'any professional group can improve the quality scores for health services not just medical and nursing'. There is a growing emphasis on interprofessional health teams to lead cohesively to meet the needs of the consumer. [1 1, 19] In order to facilitate effective interprofessional service deliveryit requires leadership with an understanding across agencies and professions involved. Evidence suggests that allied health clinicians achieve successful outcomes where they have a systems leadership role. Improved patient outcomes, reduction in wait list volumes for medical and surgical interventions and the provision of high-quality outcomes are proven results of allied health clinician led services and clinics. [2, 20]

A growing number of institutes around the world are developing health leadership competency frameworks. This is in response to the growing evidence that effective leadership is crucial to a healthcare organisations success in meeting the increasingly complex challenges of a population's health needs. In the United Kingdom's (UK) National Health Service (NHS) report 'High Quality Care for All', Darzi [21] affirms that leadership is a mechanism for change and will enhance the quality of provision to patients where the opportunities are taken up. Leadership is a central component to supporting patients towards optimal clinical outcomes and the accurate assessment of leadership performance plays a vital role in the development and improvement of leadership for healthcare organisations. [14, 22, 23]

In his research of the conceptualisation of health care leadership by medical trainees, Gordon, Rees [24] argues that the individualistic, profession-based leadership model is out of date in its capacity to respond to contemporary healthcare. Where context and educational influence play important roles in leadership conceptualisation, it is now proposed that development of health leadership is more effective than leader development within the healthcare context. [25] Therefore, the individualistic and profession-based leadership model of development is likely to 'self-perpetuate' within an individualistic workplace culture. [24] Where an individualistic profession focus perpetuates siloed leadership programmes, competency in interprofessional leadership cannot be gained. [26] Knowledge and awareness of the interplay between professions is key to leading the contemporary healthcare system and services provided. Leadership in this context is therefore required to not only acknowledge the contributing professions but their culture, identity and unique skill mix. [20]

Leadership across multiple professional groups has never been more critical. As our New Zealand (NZ) health organisations and governance structures look to their service design, effectivelyled collaboration is essential. [14] 
The NHS Improvement [27] report 'Clinical Leadership - a framework for action' emphasises 'collaborative and compassionate' leadership as one of the requirements to meet contemporary healthcare challenges (p.2). Leadership requires good communication and consultation skills to manage diverse teams. Interprofessional leadership can be demanding since it does not rely on the professional credibility as a locus of authority. [28] Recommended leadership competencies extend beyond operational skills to inherent values, behaviours and relationships. Garman, Standish [14] argues that where a leadership model does not include them it reflects a potential 'blind spot'. (P.7) Therefore, where a specialised and technical focus is required for clinical skills a more board perspective and pan-profession orientation is required for leadership. With growing evidence that the future of healthcare reform lies in leadership of interprofessional team's, literature argues it is a disadvantage to staff that their opportunities for leadership and development are not based on an interprofessional model of leadership. [14, 29] There is recognition in the literature that leadership in healthcare transcends professions, Bradd, Travaglia [30] report that allied health staff are well positioned to lead healthcare reform premised on a culture that focuses on being 'holistic, person centred, team based and inclusive'. According to Mickan, Dawber [20] allied health leaders understand the uniqueness of different professions, able to enhance patient care through the delivery of appropriate models of care.

\section{CURRENT STATE}

Comparative to the wealth of literature on health leadership premised on medical and nursing professions, there is a paucity of literature on allied health leadership in contemporary healthcare. [18, 30-34] Typically, where research has been conducted on leadership by allied health clinicians it is typically focused on the leadership of a single profession, and addresses a single profession's leadership style, behaviours or related outcomes. [4] Since 2017, Australia and the United Kingdom (UK) have begun to address allied health leadership across professional boundaries. Taking a broader view in their leadership research both Bradd, Travaglia [4], [30] and Boyce and Jackway [35] have researched the leadership experience and capacity of allied health professions across multiple professions. While in the UK, the NHS Improvement forum has recently published reports addressing the current state of Allied Health leadership and designed a framework to support leadership development. [27, 36] The NHS Improvement [36] research collated information from allied health leaders leading allied health professions as well as those in senior leadership they reported to. It provided new information on the lack of organisational governance infrastructure supporting allied health services and the impact it had on delivery and productivity. The study also had a second focus on the 'characteristics, key skills and attributes of effective AHP leaders' and how they had been gained (p.15). Despite this progress little is understood about the barriers or enablers to allied health staff progressing into systems leadership roles.

As evidenced by the literature, Australia and the UK have made significant progress into the allied health leadership research field. [30, 35-37] It is argued that one of their key drivers for research is the lack of established and unified allied health leadership roles. [36] Conversely, in NZ there are strategic allied health leadership roles at every DHB executive board level but a lack of evidence to support the efficacy and impact of the existing allied health leadership. This absence of evidence exists across leadership capability and the requirements for development of future leaders. While the gap in research exists, it is a challenge to understand how to support the leadership of healthcare by allied health professionals and increase their potential for impactat the strategic and health reform level. There are many avenues of research available and key drivers include the current transformational shift in healthcare towards cohesive and integrated services, the recent appointment of a chief allied health professions officer and the predominance of non-allied health staff in governance roles. [1 1 ]

Wylie and Gallagher [32] argued that it is vital that allied Health professions develop leaders to fulfil their potential by seizing opportunities presented in the redesign of health care services. They suggested that having the leadership capacity would support allied health leaders in contributing to the services most in need of reform and improvement. This is affirmed by the Australian study of allied health leadership perceptions by Bradd, Travaglia [30] which reports not only is there under-representation of allied health professions in health system change roles but that allied health leaders feel 'powerless to affect health system change compared to their colleagues' (p.2).

There is a lack of empirical evidence regarding the added value of allied health leadership is clear but what there is 
identifies a connection between successful health outcomes and effective allied health leadership. [4, 18] According to Markham [2] allied health is 'front seat' to lead changes in health system using leadership, workforce model changes and a focus on prevention and early intervention. Mickan, Dawber [20]'s study reported executives described allied health leaders as 'influential' in the development of new models of care, using collaborative models of service delivery 'adding value' to business and improved outcomes for consumers.

\section{BARRIERS AND ENABLERS}

According to Orton and Hocking [13] allied health professionals may not always take leadership opportunities due to a lack of recognition of their own potential. The context in which they practice may also influence their perceptions of leadership. Wylie and Gallagher [32] studied the transformational behaviours in allied health leaders and identified that if new allied Health professional graduates do not receive leadership development training the context in which they practice is likely to make them resistant to change. Conversely Bradd, Travaglia [37] identify that there is success in improving outcomes for healthcare when allied health leadership training is provided, without stipulating timing of provision. Regardless of when the training is provided it is evident that training and development is effective in creating leadership capability. [23] Consideration of context also includes organisational culture. If allied health leadership is not supported within the organisational culture, then there can be a negative impact on organisational performance. [38]

A key report published in the UK [39] identifies a dominance of medical and nursing professionals in leadership roles. This finding aligns with a previous study for New Zealand published by Gauld and Horsburgh. [39] That report [39] made key recommendations to support the increase of clinicians into senior leadership roles, drawing on leadership across 'all relevant clinical professions'. [40] While the recommendations were inclusive the study sample was not and the majority of views were provided by medical and nursing staff, limiting the generalisability of their findings. An indication that medical leaders can be more easily identified, is substantiated by Gordon, Rees [24] who reported in his research that participating trainee doctors saw their role as one which should be taking the lead.
Literature identifies that context and education play significant roles in how leadership is perceived, this suggests that leadership culture change is associated closely with training. [24] Training is required to develop the insights and tools to lead effectively in 'volatile, uncertain, complex and ambiguous situations. [23, 41] Considering context, a lack of professional partnership and interprofessional engagement undermine the ability to contribute to strategic and operational elements of health care planning and service provision. [39] All clinicians, including allied health professions need to be viewed as equals rather than through a hierarchical perspective. Where recruitment is specified to a profession, rightly or wrongly, it does not allow for the employment of the most appropriate person and could lead to the inequity of opportunities for staff to lead. This in turn can lead to allied health professionals feeling disempowered in comparison to their colleagues. [30]

\section{CONCLUSION}

The international literature affirms expanding the scope of clinicians in systems leadership roles. [40] The allied health workforce are called to step forward and lead, that they may be understood and use their valued skills to help shape New Zealand's health and disability system. [42] While New Zealand supports allied health clinicians in health systems leadership roles, there remains an inequitable representation across the health and disability system. Contextualised research is required in order to understand what factors, enable or limit allied health clinicians stepping into health systems leadership roles. These research findings could be used to inform the Ministry of Health, senior allied health leaders, health organisations and the allied health community. The information could be used to develop frameworks and policy that will support, develop and sustain allied health clinicians leading across the health and disabilitysystem.

\section{References}

1. Swanwick T, McKimm J. What is clinical leadership... and why is it important? The Clinical Teacher. 2011 1:8:22-6.

https://onlinelibrary.wiley.com/doi/pdf/10.1111/j.1743498X.2010.00423.X 
2. Markham D. Allied health: leaders in health care reform. Aust Health Rev. 2015;39(3):248.

https://pdfs.semanticscholar.org/3597/de3b0002c1767 1b4c2a20fd7e3f4e48d8d62.pdf? ga=2.180876514.419 612565.1591853125-1519573501.1591853125

3. Marinelli-Poole A, McGilvray A, Lynes D. New Zealand health leadership. Leadership in Health Services (1751 1879). $2011 ; 24(4): 255$.

https://ezproxy.aut.ac.nz/login?url=https://search.ebs cohost.com/login.aspx? direct=true \& $\mathrm{db}=e \mathrm{db} \& A \mathrm{~N}=703$ 61899\&site=eds-live

4. Bradd P, Travaglia J, A H. Leadership in Allied Health: A review of the Literature. Asia Pac J Health Management. 2017;12(1):17-24

5. Gauld R, Horsburgh S. Clinical governance: an assessment of New Zealand's approach and performance. Clin Govern Int J. 2015;20(1):2-12. http://search.ebscohost.com/login.aspx? direct=true\& $\underline{\mathrm{db}=\mathrm{ccm} \& \mathrm{AN}=103779143 \& \text { site }=\text { ehost-live \&scope }=\text { site }}$

6. McGowan E, ElliottN, Stokes E. Leadership Capabilities pf physiotherapy leaders in Ireland: Part 1 physiotherapy managers. Physiother Theory Pract. 2018;35(1 1):1027 - 43.

https://doi.org/10.1080/09593985.2018.1469178

7. Green B, Johnson C, Adams A. Writing narrative literature reviews for peer-reviewed journals: secrets of the trade. J Chiropr Med. 2006:5(3):101-17. https://doi.org/10.1016/S0899-3467(07)60142-6

8. Department of Prime Minister and Cabinet. Our Health and Disability System: Building a stronger health and disability system that delivers for all New Zealanders. Wellington; 2021.

https://dpmc.govt.nz/sites/default/files/2021 04/heallth-reform-white-paper-summary-apr21.pdf

9. Minister of Health. DHB Governance:District Health Board Committees: New Zealand Government; 2000 [Available from:

https://www.beehive.govt.nz/feature/dhbgovernance-district-health-board-committees.

10. Ministry of Health. New Zealand Health Strategy: Future Direction. Wellington: Ministry of Health; 2016. https://www.health.govt.nz/system/files/documents/p ublications/new-zealand-health-strategyfuturedirection-2016-apr 16.pdf

11. Health and Disability System Review. Health and Disability System Review / Arotake Pūnaha Hauora, Whaikaha Hoki: Final Report /Pūronga
Whakamutunga. Wellington; 2020 March 2020. https://systemreview.health.govt.nz/assets/Uploads/h dsr/health-disability-system-review-final-report.pdf

12. Brown J, Connolly A, Dunham R, Kolbe A, Pert H. In Good Hands. Ministry of Health, Leadership MTGoC; 2009.

https://www.beehive.govt.nz/sites/default/files/In\%20 Good\%20Hands\%20Report.pdf

13. Orton $Y$, Hocking C. Clinical governance: Implications for occupational therapists in Aotearoa New Zealand. New Zealand Journal of Occupational Therapy.

2017;64(1):14-8.

http://search.ebscohost.com/login.aspx? direct=true\& $\underline{\mathrm{db}=c \mathrm{~cm} \& \mathrm{AN}=122651200 \& \text { site }=\text { ehost-live \&scope }=\text { site }}$

14. Garman AN, Standish MP, Wainio JA. Bridging worldviews: Toward a common model of leadership across the health professions. Health Care Manage Rev. 2019.

http://search.ebscohost.com/login.aspx? direct=true\&

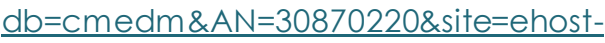
live\&scope $=$ site

15. Mianda S, Voce AS. Conceptualizations of clinical leadership: a review of the literature. Journal of Healthcare Leadership. 2017:9:79-87.

https://www.dovepress.com/conceptualizations-ofclinical-leadership-a-review-of-the-literature-peerreviewed-fulltext-article-JHL

16. i3 Institute for Innovation and Improvement. Health Leadership: Waitemata DHB; 2021 [Available from: https://i3.waitematadhb.govt.nz/about/programmes/.

17. HealthLearn. Leadership Excellence 2021 [cited 2021. Available from:

https://www.healthlearn.ac.nz/course/index.php?cat egoryid $=165$.

18. McKeever J, Brown T. What are the Client, Organisational and Employee - Related Outcomes of High Quality Leadership in the Allied Health Professions? A Scoping Review. Asia Pac J Health Management. 2019;14(2):19-30.

https://ezproxy.aut.ac.nz/login?url=https://search.ebs cohost.com/login.aspx? direct=true \& db=bth\&AN=1379 57769\&site=eds-live

19. McGrath ER, Bacso DR, Andrews JG, Rice SA. Intentional interprofessional leadership in maternal and child health. Leadership in Health Services (17511879). 2019;32(2):212-25.

http://search.ebscohost.com/login.aspx?direct=true\& $\underline{\mathrm{db}=c \mathrm{~cm} \& \mathrm{AN}=135722369 \& \text { site }=\text { ehost-live \&scope }=\text { site }}$ 
20. Mickan S, Dawber J, Hulcombe J. Realist evaluation of allied health management in Queensland: what works, in which contexts and why. Aust Health Rev. 2019;43(4):466-73.

https://www.publish.csiro.au/ah/pdf/AH1 7265

21. Darzi L. NHS Next Stage Review Final Report: High Quality Care for All.Department of Health, NHS; 2008. https://assets.publishing.service.gov.uk/government/u ploads/system/uploads/attachment data/file/228836 17432.pdf

22. Hui-Gek A, Meng-Yeow Koh J, Jeffrey L, Yong-Hao P. Development and preliminary validation of a leadership competency instrument for existing and emerging allied health professional leaders. BMC Health Serv Res. 2016;16:1-8.

https://bmchealthservres.biomedcentral.com/track/p df/10.1186/s12913-016-1301-1

23. Scott J, Simpson B, Skelton-Green J, Munro S. Building Healthcare Leadership Capacity: Strategy, Insights and Reflections. Nursing Leadership (1910-622X). 2018;31 (4):10-21.

http://search.ebscohost.com/login.aspx?direct=true \& $\underline{\mathrm{db}=c \mathrm{~cm} \& A N=135037064 \& \text { site }=\text { ehost-live \&scope }=\text { site }}$

24. Gordon LJ, Rees CE, Ker JS, Cleland J. Dimensions, discourses and differences: trainees conceptualising health care leadership and followership. Med Educ. 2015;49(12):1248-62.

http://search.ebscohost.com/login.aspx? direct=true\&

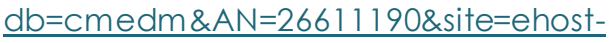
live\&scope=site

25. Edmonstone J. What is wrong with NHS leadership development? British Journal of Healthcare Management. 2013;19(11):531-8. http://search.ebscohost.com/login.aspx? direct=true\& $\underline{\mathrm{db}=c \mathrm{~cm} \& \mathrm{AN}=91961553 \& \text { site }=\text { ehost-live \&scope=site }}$

26. Akhtar M, Casha JN, Ronder J, Sakel M, Wight C, Manley K. Leading the health service into the future: transforming the NHS through transforming ourselves. International Practice Development Journal.

2016;6(2):1-21.

http://search.ebscohost.com/login.aspx? direct=true\&

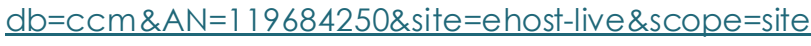

27. NHS Improvement. Clinical Leadership - a framework for action. Wellington House, London; 2019. https://improvement.nhs.uk/documents/3702/Clinical leadership - framework Jan2019.pdf
28. Smith T, Fowler-Davis S, Nancarrow S, Ariss SMB, Enderby P. Leadership in interprofessional health and social care teams: a literature review. Leadership in Health Services (1751-1879). 2018;31 (4):452-67.

http://search.ebscohost.com/login.aspx? direct=true\& $\mathrm{db}=\mathrm{ccm} \& \mathrm{AN}=131882055 \&$ site $=$ ehost-live \& scope $=$ site

29. Boyce B. Learning to Lead: Developing Dietetics Leaders. J Acad Nutr Diet. 2014;1 14(5):688-92. http://www.boycegroupinc.com/images/Leaders.pdf

30. Bradd P, Travaglia J, Hayen A. Allied health leadership in New South Wales: a study of perceptions and priorities of allied health leaders. Aust Health Rev. 2018;42(3):316-20.

http://search.ebscohost.com/login.aspx? direct=true\&

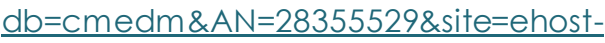
live\&scope=site

31. Gifford WA, Squires JE, Angus DE, Ashley LA, Brosseau L, Craik JM, et al. Managerial leadership for research use in nursing and allied health care professions: a systematic review. Implement Sci. 2018;13(1):127. https://www.ncbi.nlm.nih.gov/pmc/articles/PMC61613 44/pdf/13012 2018 Article 817.pdf

32. Wylie DA, Gallagher HL. Transformational leadership behaviors in allied health professions. J Allied Health. 2009;38(2):65-73.

https://www.researchgate.net/publication/26687319 Transformational leadership behaviors in allied healt h professions

33. 33. McNabb D. Professional leadership for social work in state mental health services in Aotearoa New Zealand. Aotearoa New Zealand Social Work Review. 2009;21/22(4/1):103-8.

https://ezproxy.aut.ac.nz/login?url=https://search.ebs cohost.com/login.aspx? direct=true $\& \mathrm{db}=a$ anh $\& A N=513$ 76390\&site=eds-live

34. McGowan E, ElliottN, Stokes E. Leadership capabilities of physiotherapy leaders in Ireland: Part 2. Clinical Specialists and advanced physiotherapy practitioners. Physiother Theory Pract. 2018;35(1 1):1044-60. https://www.tandfonline.com/loi/iptp20

35. Boyce R, Jackway P. Allied Health Leaders: Australian Public Sector Health Boards and Top Management Teams. Melbourne, Australia: Department of Health \& Human Services, Office of the Chief Allied Health Advisor; 2017 April. https://www2.health.vic.gov.au/Api/downloadmedia/ \%7B7605D12C-8B4A-418F-B209-8FB1600060A1\%7D 
36. NHS Improvement. Leadership of allied health professions in trusts: what exists and what matters.

Wellington House, London: NHS Improvement; 2018. https://improvement.nhs.uk/documents/2904/Leaders hip of AHPs in trusts.pdf

37. Bradd P, Travaglia J, Hayen A. Developing allied health leaders to enhance person-centred healthcare. Journal of health organization and management. 2018;32(7):908-32.

http://search.ebscohost.com/login.aspx? direct=true\&

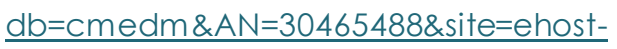

live\&scope=site

38. Mannion R, Davies H, Marshall M. Cultural characteristics of "high" and "low" performing hospitals. J of Health Organ and Manag. 2005;19(6):431-9.

http://search.ebscohost.com/login.aspx? direct=true\& $\mathrm{db}=\mathrm{cmedm} \& \mathrm{AN}=16375066 \&$ site=ehostlive\&scope=site

39. Gauld R, Horsburgh S. Healthcare professionals' perceptions of clinical governance implementation: a qualitative New Zealand study of 3205 open-ended survey comments. BMJ open. 2015;5(1):e006157. http://search.ebscohost.com/login.aspx? direct=true\&

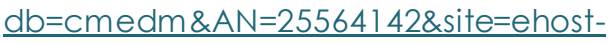
live\&scope =site

40. Faculty of Medical Leadership and Management. Review Report: Barriers and enablers for Clinicians moving into senior leadership roles. 201815 November.

https://assets.publishing.service.gov.uk/government/u ploads/system/uploads/attachment data/file/756483 /Clinical_leadership_report_f.pdf

41. Impact International. Leadership in a VUCA World. 2012.

https://www.impactinternational.com/blog/2012/01/l eadership-vuca-world

42. Fry K. Social work clinical leadership in allied health. Aotearoa New Zealand Social Work Review.

2009;21/22(4/1):109-13.

https://ezproxy.aut.ac.nz/login?url=https://search.ebs cohost.com/login. aspx? direct=true \& $\mathrm{db}=\operatorname{sih} \& A N=5137$ $\underline{6391 \& \text { site }=e d s-l i v e}$ 